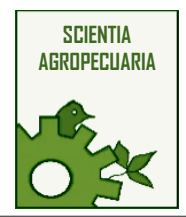

Scientia Agropecuaria

Web page: http://revistas.unitru.edu.pe/index.php/scientiaagrop
Facultad de Ciencias

Agropecuarias

Universidad Nacional de Trujillo

\title{
REVIEW
}

\section{Phenolic compounds of mango (Mangifera indica) by-products: Antioxidant and antimicrobial potential, use in disease prevention and food industry, methods of extraction and microencapsulation}

\author{
Vicente Tirado-Kulieva1 $\mathbb{D}^{\mathbb{D}}$; Sheyla Atoche-Dioses ${ }^{1 \mathbb{D}}$; Ernesto Hernández-Martínez ${ }^{1, *}{ }^{(\mathbb{D})}$ \\ Universidad Nacional de Frontera, Facultad de Ingeniería de Industrias Alimentarias, Escuela de Ingeniería de Industrias Alimentarias, \\ Av. San Hilarión No 101, Sullana, Piura. Peru. \\ *Corresponding author: ehernandez@unf.edu.pe (E. Hernández-Martínez).
}

Received: 28 November 2020. Accepted: 14 April 2021. Published: 1 June 2021.

\begin{abstract}
Globally, a large amount of agri-food waste is generated as a result of industrial processes or direct consumption of raw materials, and when discarded, they represent a factor of environmental pollution. Mango by-products have a great bioactive potential, especially because they contain phenolic compounds in which mangiferin predominates, in addition to a great variety of phenolic acids, flavonoids and tannins, which confer antioxidant effects against cancer, cardiovascular and neurological diseases, among others. In addition, it was demonstrated that they have an effect against a broad microbial spectrum, including multiple pathogenic bacteria and fungi such as Escherichia coli and Candida albicans, respectively. According to the literature, mango peel and seed extracts also have potential as an additive, by influencing the sensory and physicochemical characteristics of foods, which has been proven by their addition to products such as shrimp, yogurt and cookies. Considering the importance of mango by-products, this work focused on their phenolic properties, the mechanism of antioxidant and antimicrobial action, their fields of pharmacological and food applications, in addition to evaluating their extraction methods and proposing microencapsulation as a suitable technology to avoid their degradation and control their release under appropriate conditions. Based on the analysis performed, further studies are suggested on the application in different foods and to evaluate the interaction of polyphenols with the compounds of the product, to avoid possible negative effects. It is also recommended to experiment with the use of combined technologies to improve results during extraction and microencapsulation.
\end{abstract}

Keywords: Fruit, seed; peel; phytonutrients; mangiferin; flavonoids; anti-inflammatory; food processing.

DOI: https://dx.doi.org/10.17268/sci.agropecu.2021.031

Cite this article:

Tirado-Kulieva, V., Atoche-Dioses, S., \& Hernández-Martínez, E. (2021). Phenolic compounds of mango (Mangifera indica) by-products: Antioxidant and antimicrobial potential, use in disease prevention and food industry, methods of extraction and microencapsulation. Scientia Agropecuaria, 12(2), 283-293.

\section{Introduction}

In agro-industrial processes, large quantities of byproducts are generated that are not of interest and as they have not economic value, only a part is reused (Struck \& Rohm, 2020). When they are discarded, during their decomposition they produce gases that cause impact to the environment, in addition to being a source of microorganisms that are harmful to the health of people and other living beings (Shirahigue \& Ceccato-Antonini, 2020; Sumaya-Martínez et al., 2019). The by-products that are also produced from the consumption of raw materials, are an important source of antioxidants, represented especially by phenolic compounds (Velderrain-Rodríguez et al., 2019), which, based on Siacor et al. (2020), their demand is increasingly in the international market, projecting their annual economic value to increase by
7.2\% from 2019 to 2025. Mango (Mangifera indica) is one of the most widely produced and consumed fruits (Mwaurah et al., 2020), due to its delicious flavor, aroma, color and nutritional value (Lebaka et al., 2021) and according to $\mathrm{FAO}$, its production in 2018 was 52.08 million metric tons (Marcillo-Parra et al., 2021), representing more than $50 \%$, in terms of tropical fruits (Alañon et al., 2021). It has great antioxidant potential as it contains compounds such as retinol (El-Desoukey et al., 2020), ascorbic acid, carotenoids (Ribeiro et al., 2008) and phenolic compounds such as mangiferin (Figure 1), anthocyanins, kaempferol, quercetin, catechin, rhamnetin, gallic acid, benzoic acid, ellagic acid, tannins, flavonols, benzophenone and their derivatives (Dorta et al., 2014; Mwaurah et al., 2020), which are mainly found in the peel and the seed (Ribeiro et al., 2008). 

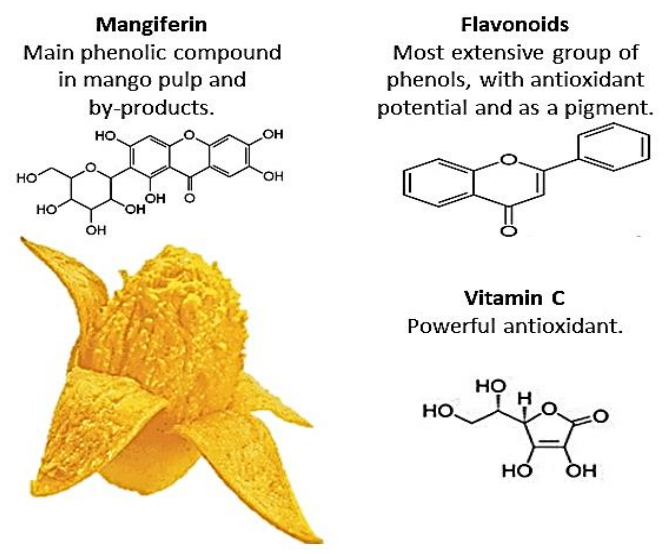

Vitamin C

Powerful antioxidant.

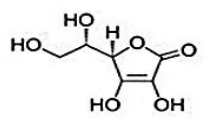

Figure 1. Antioxidant potential of mango.

Despite its importance, during its processing and/or consumption, especially in juice, concentrated pulp, jam, puree, nectar or other related product (Rojas et al., 2018), high volumes of residues such as seeds and peels are generated, ranging from $35 \%$ to $60 \%$ of the weight of the fruit, although they contain bioactive compounds of interest (Meneses et al., 2015; Sumaya-Martínez et al., 2019), especially from the phenolic group as shown in Figure 2.

Considering the previous, besides containing the mentioned vitamins and also, tocopherol (SumayaMartínez et al., 2019), synergistically, they provide the byproducts with excellent pharmacological attributes such as: antiatherogenic, antitumoral (Ribeiro et al., 2008), antiinflammatory, antimicrobial and anticancer being represented especially by mangiferin, the main compound present in the mango (Castro-Vargas et al., 2019; Meneses et al., 2015). Due to their properties, they present a great interest in the food industry, being able to use them as natural additives in replacement of synthetic ones, obtaining healthier foods and preventing malnutrition (Mwaura et al., 2020). In this context, by giving them an added value, in addition to providing an improvement in economic terms (Ordoñez-Torres et al., 2020; Shirahigue \& Ceccato-Antonini, 2020), their correct use would help reduce environmental and health problems caused by their decomposition (Sumaya-Martínez et al., 2019).
As shown, mango peel and seed have a large number of phenolic families and in addition to those detailed, they contain derivatives of the same. For example, OrdoñezTorres et al. (2020) identified in the peel, compounds such as galloyl glucose, gallic acid 3-O-gallate, tetra-galloyl glucose, among other derivatives. Likewise, Lebaka et al. (2021) indicate that the seed presents polyphenols such as cyanidin, mangiferin gallate, homomangiferin, isomangiferin, isomangiferin gallate, and rhamnetin 3-0 galactoside/glucoside. Despite the characteristics and phenolic properties of mango by-products, Lim et al. (2019) indicate that they can be easily degraded during processing and storage and can suffer darkening and even alterations in their antioxidant qualities. Therefore, El-Messery et al. (2021) mention that conservation technologies such as microencapsulation should be applied.

In addition to preserving the phenolic characteristics of external factors such as oxygen, water, light (VelderrainRodríguez et al., 2019), pH and moisture, it also has benefits such as masking odors, enhancing flavors, and facilitating their use in desired conditions (Siacor et al., 2020).

Bioactive compounds are becoming increasingly popular in the industry, since they have diverse qualities and benefits for humans, and even more so if they are derived from agroindustrial waste, since adding value to them would contribute economically and mitigate the pollution they usually generate. In this regard, the objective of this review was to gather information on the antioxidant and antimicrobial characteristics of phenolic compounds from mango peel and seed, as well as to report on their potential pharmacological applications and especially as an additive in the food industry.

\section{Mechanism of antioxidant and antimicrobial action 2.1 Antioxidant potential}

According to several studies, free radicals oxidize DNA, proteins, lipids and other compounds in living organisms, specifically in humans, being related to the appearance or progression of cancerous, cardiovascular, respiratory and even neuronal diseases (Huang et al., 2018). These effects can be inhibited by flavonoids that as mentioned by Ochoa \& Ayala (2004), they have 20 and 50 times more antioxidant activity than ascorbic acid and tocopherol, respectively.

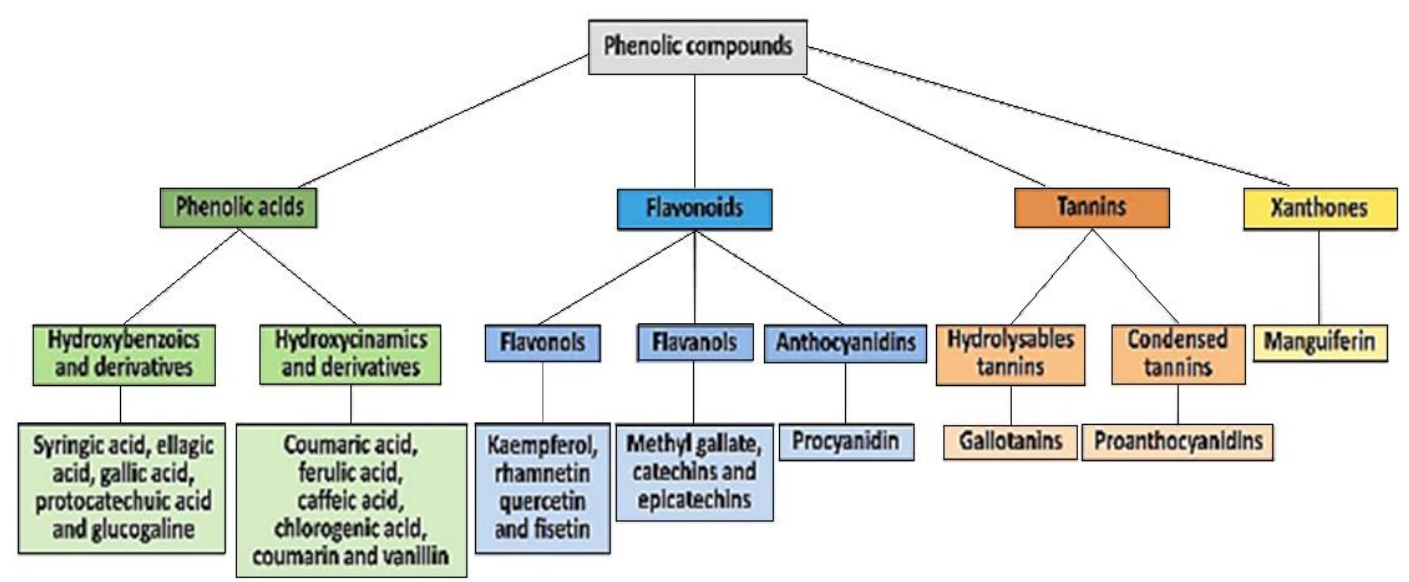

Figure 2. Classification of phenolic compounds contained in mango peel and seed. Based on information from Bai et al. (2018); BenOthman et al. (2020); Dorta et al. (2014); Masibo and He (2008); Mercado (2014). 
Mango has attracted the attention of researchers for its quantity and variety of polyphenols, and its antioxidant potential. According to study of Mercado (2014), it was concluded that mango pulp has higher total phenolic content than fruits such as grape, blackberries, strawberries and pineapples, and therefore a higher antioxidant capacity: $174.3 \mathrm{mg}$ of vitamin C equivalent/100g for DPPH (2,2 diphenyl-1-picryhydrazyl) assay. Considering by-products, Ribeiro et al. (2008) focused on the mango variety 'Ubá' and in their research, the peel presented a total phenolic content of 57.24 $\mathrm{mg} / \mathrm{kg}$ of dry matter and $82.54 \mathrm{mg} / \mathrm{kg}$ in the seed. Likewise, the peel and seed extracts showed 89 and $60.7 \%$ radical inhibition by the DPPH method, in addition to a reducing power of 0.97 and 1.05 , respectively, at a concentration of 5000 ppm.

In the investigation of Soong \& Barlow (2004), the mango seed had higher antioxidant activity than tamarind and avocado. The values using the Folin-Ciocalteu reagent (FCR) were 117, 94.5 and $88.2 \mathrm{mg}$ of gallic acid equivalent (GAE)/g for mango, avocado and tamarind, respectively. Previous studies compile by Mercado (2014) reported higher total phenol content in mango seed extracts (2572 mg GAE/g) compared to $1144 \mathrm{mg}$ GAE/100g in apple, $2335 \mathrm{mg} \mathrm{GAE} / 100 \mathrm{~g}$ in grapefruit and $820 \mathrm{mg}$ GAE/100g in kiwi. Furthermore, the antioxidant capacity of mango seed (4188 $\mu \mathrm{mol}$ Trolox equivalent (TE)/g) and peel (1846 $\mu \mathrm{mol}$ $\mathrm{TE} / \mathrm{g}$ ) is very high compared to $462 \mu \mathrm{mol} \mathrm{TE} / \mathrm{g}$ from avocado seed, $75.4 \mu \mathrm{mol}$ TE/g from passion fruit peel and $58.4 \mu \mathrm{mol} \mathrm{TE} / \mathrm{g}$ from papaya peel. Particularly, in the research of Meneses et al. (2015), they determined the phenolic content of the extract of a mixture of Tommy Atkins and Haden mango peels, with the addition of pulp, which was $29545 \mathrm{mg} \mathrm{GAE} / \mathrm{kg}$.

Vega-Vega et al. (2013) indicates that phenolic compounds protect the human cells against oxidation factors. Masibo \& He (2008) mention that they have prevent the oxidative damage of the DNA, to eliminate the free radicals, preventing alterations in the organism and specifically, degenerative diseases and aging. According to Minatel et al. (2017), phenolic compounds stabilize free radicals by giving up hydrogen atoms or electrons, as well as chelating metals important for oxidation enzymes. Another mode of antioxidant action of phenolic compounds is their inhibitory effect on the formation of hydroperoxides (Maqsood et al., 2014) from the lipid peroxidation of, for example, a monounsaturated fatty acid, preventing its oxidation by free oxygen radicals (commonly catalyzed by metal ions) or by enzymes such as lipoxygenases (Figure 3).

Mangiferin, the major phenolic component present in mango residues, is the main cell protector and according to Masibo \& He (2008), its activity as an antioxidant agent is present even in low concentration.

\subsection{Antimicrobial potential}

Pathogenic microorganisms in humans and animals are increasingly resistant to drugs due to their misuse or overuse. These are especially synthetic which also cause side effects in the consumer's body, therefore, there is a need for new high spectrum antimicrobial agents with few or no side effects (Huang et al., 2018), which could also be used in food, since microorganisms are the main cause of the deterioration of their characteristics, altering their quality.

Phenolic compounds have a high antimicrobial effect by causing structural or functional damage in the cell membrane, due to the adsorption of phenols, the interaction with enzymes, with hydrophilic amino acids of proteins, causing an alteration of the $\mathrm{pH}$ and electrical potential (Raybaudi-Massilia et al., 2009), the deprivation of metallic ions, this by the action of phenolic acids, specifically. Also, the coagulation and leakage of the cellular content by the effect of gallic acid (Mercado, 2014), the formation of harmful complexes by the synergistic action with flavonoids (Bouarab-Chibane et al., 2019), alteration of the genetic system and therefore, death (Figure 4). According to several studies, the extract of the mango seed Haden, Ataulfo and Tommy Atkins had an antimicrobial effect against Salmonella spp., Escherichia coli O157:H7, Listeria monocytogenes, Staphylococcus spp., among others. Mango var. Haden specifically demonstrated impact against bacteria such as Bacillus cereus, B. subtilis, Pseudomonas aeruginosa, Vibrio vulnificus, Salmonella typhi and Clostridium spp. (VegaVega et al., 2013). Similarly, mango peel extract showed a high effect against Staphylococcus aureus, E. coli, P. aeruginosa, B. cereus, Candida albicans (El-Desoukey et al., 2020), S. typhi, Shigella spp., Enterobacter spp., Aspergillus niger (Thambi et al., 2016), Colletotrichum gloeosporioides, Sclerotinia sclerotiorum, Fusarium oxysporum and Mucor sp (Rojas et al., 2018).

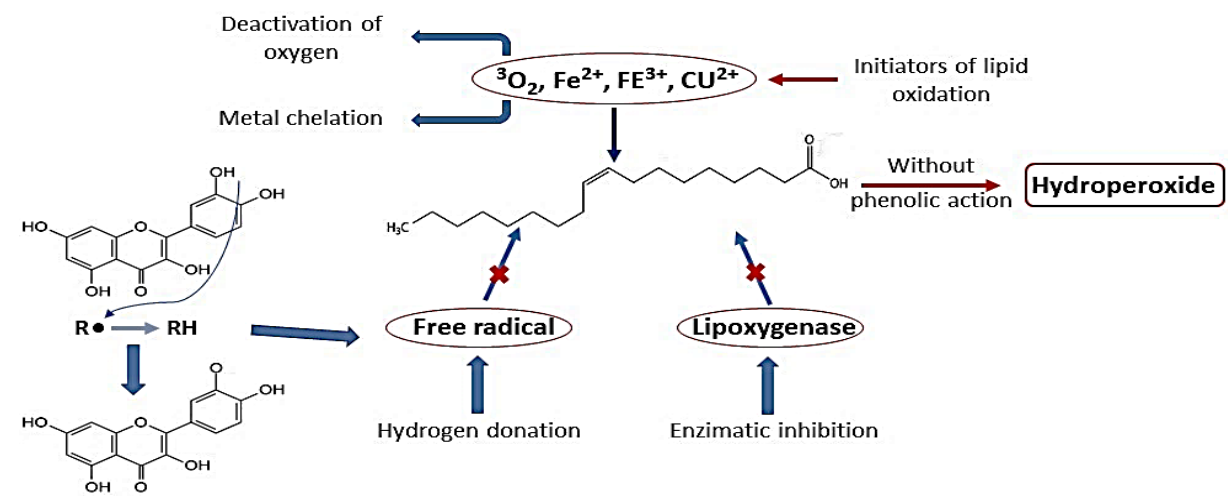

Figure 3. Effect of phenolic compounds preventing the formation of hydroperoxide from oleic acid by various mechanisms. Adapted from Maqsood et al. (2014). 


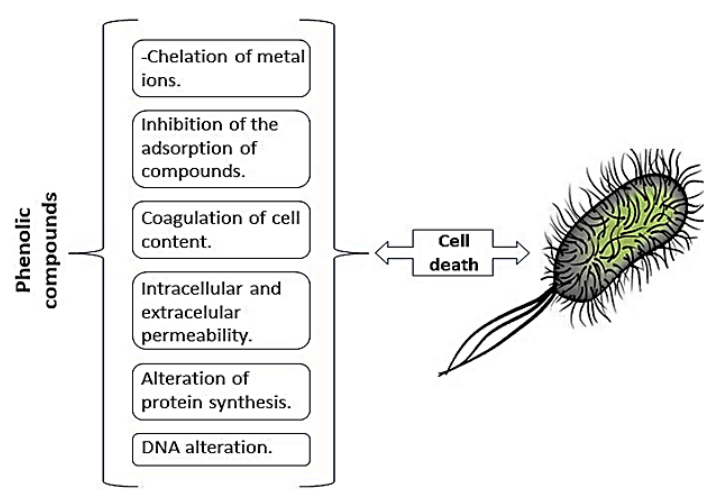

Figure 4. Effects of phenolic compounds on microorganisms, until their death.

Dorta et al. (2016) conducted tests on the fungal activity of the seed and peel of Keitt, Sensation and Gomera mangoes. Their extracts showed inhibitory effect against multiple yeasts of the genera Saccharomycodes, Lodderomyces, Hanseniaspora, Candida, Dekkera, Metschnikowia, Schizosaccharomyces, Zygosaccharomyces and Pichia. According to the analyses performed, it was determined that this property was related to the presence of gallates, gallotannins and proanthocyanidins. In an in vivo experiment, Gómez-Maldonado et al. (2020) using a solution with of Ataulfo mango seed extract (3 g/L) with $461.7 \mathrm{mg} \mathrm{GAE} / \mathrm{g}$ and DPPH activity of $2919.0 \mu \mathrm{mol}$ $\mathrm{TE} / \mathrm{g}$, achieved, by immersion of mango fruits, total mycelial inhibition of Colletotrichum brevisporum (inoculated at 105 spores $/ \mathrm{mL}$ ) at 9 days and of its spores, at $20 \mathrm{~h}$.

According to the background, the antibacterial effect of phenolic compounds in mango by-products is more efficient against Gram-positive ones, confirmed by Huang et al. (2018) which argue the low susceptibility of Gramnegative due to the lipopolysaccharides present in their membrane, making them more resistant, repelling or slowing down the interaction with polyphenols.

\section{Application of phenolic compounds}

The phenolic potential of mango by-products, (19.06 and $23.9 \mathrm{mg} \mathrm{GAE} / \mathrm{g}$, and 93.89 and $95.08 \%$ inhibition of the DPPH radical, in the peel and seed, respectively, according to Ashoush \& Gadallah, 2011), qualify them as key ingredients in the production of pharmacological products since, according to several studies, they have also demonstrated other properties such as antimutagenic activity (Kantrong \& Eshtiaghi, 2018), anti-inflammatory, antiallergic, antidiabetic, antihyperlipemic antiproliferative, antiplatelet, antiaging, as an immunomodulator and even, against neurological diseases, respiratory, hemorrhagic (Lebaka et al., 2021) and defense against breast, liver, leukemia, cervical, prostate, lung and colon cancer (Alañon et al., 2021). In addition to those mentioned, by presenting functional characteristics such as antioxidant, biopreservative, coloring and flavoring, they are qualified as ideal ingredients for the food industry (Mwaurah et al., 2020), specifically in the field of nutritional products (Marcillo-Parra et al., 2020), also promoting a culture of maximum utilization of food (Zepeda-Ruiz et al., 2020).

\subsection{Disease prevention}

\subsubsection{Anti-cancer and cardiovascular disease}

Mercado (2014) concluded in her research that gallotannins from mango seed extract had antiproliferative effect against cancer cells of liver (HepG2), breast (MDAMB-231) and leukemia (HL-60).

Studies indicate that proanthocyanidins and tannins have the potential to prevent digestive and other internal organ cancers. They also prevent oxidation of low-density lipids $(\mathrm{LDL})$ and blood clotting, thus avoiding cardiovascular diseases (Vermerris \& Nicholson, 2006).

Similarly, research has shown that there is a high correlation between polyphenol levels, especially flavonoids, and the prevention of cancer and cardiovascular diseases, platelet disorders, etc., as well as boosting the immune and metabolic systems (Minatel et al., 2017).

According to Gordo (2017), flavonoids prevent cancer by blocking the cycle of cancer cells at a certain stage and apoptosis, in addition to preventing oxidation, inducing detoxification enzymes (Phase I and Phase II).

Martínez-Flórez et al. (2002) conducted an in vitro experiment in which they concluded that quercetin prevents breast cancer, possibly due to its powerful capacity to inhibit aromatase, which is responsible for the biosynthesis of estrogens. It also increases the concentration of glutathione in the body, which has an impact on the prevention of lipid peroxidation caused by iron.

According to Quiñones et al. (2012), polyphenols have effectively inhibited the angiotensin converting enzyme (ACE), a potent vasoactive and blood pressure regulator, which would justify the vasodilatory and cardioprotective effects of phenols. In addition, they have an antithrombotic effect since anthocyanins inhibit platelet function, preventing the formation of clots inside the arteries and veins.

\subsubsection{Anti-inflammatory}

Hole et al. (2012) highlight the anti-inflammatory activity of caffeic, coumaric, synapic and ferulic acid in a synergistic way on the activity of the protein complex (NFKB), a complex involved in inflammation, stress responses, differentiation and activation of immune cells. Similarly, Tanase et al. (2019) stated that this property of phenols is due to their mechanism of blocking the overproduction of tumor necrosis factor (TNF- $\alpha$ ), a protein that also executes functions related to inflammation.

Flavonoids avoid the risk of inflammation (Vermerris \& Nicholson, 2006) and together with proanthocyanidins help in the absorption, protection and prolongation of the functions of vitamin C, such as the preservation of collagen (a protein that forms tissues) against enzymatic activity, damage by free radicals and the synthesis of inflammatory agents (Ochoa \& Ayala, 2004). Quercetin has the same potential due to its cyclooxygenase (COX) and lipid peroxidation (LPO) inhibitory effect (Quiñones et al., 2012).

\subsubsection{Neuroprotector}

The reports of Alañon et al. (2017) highlighted the effect of phenolic compounds against neurodegenerative problems. Lemus-Molina et al. (2009) corroborated that 
information when they determined in vivo in the cerebral cortex of rats that mangiferin successfully protected neuroblastoma cells from oxidation deliberately induced by hydrogen peroxide. Similarly, according to Masibo \& $\mathrm{He}$ (2008), mangiferin reduced the intracellular concentration of $\mathrm{Ca}^{2+}$ in the brains of gerbils, demonstrating its property against neurological diseases, especially preventing neuronal death.

The effect of quercetin, caffeic acid, catechin and epicatechin on the inhibition of 5-S cysteinyldopamine (Alañon et al., 2017), a neurotoxin that influences the progression of Parkinson's, has been reported.

Regarding flavonoids, Alañon et al. (2017) mention that they have neuroprotective action, due to their influence in modulating cell signaling, to suppress neuroinflammation by reducing the release of cytokines, decreasing proinflammatory factors and transcription pathways.

\subsubsection{Antidiabetic}

Bhuyan \& Basu (2017) described the anti-diabetic mechanism of phenolic compounds. They inactivate $\alpha$-amylase, $\alpha$-glucosidase, maltase-glucoamylase and sucraseisomaltase, fundamental enzymes in carbohydrate degradation. Martín et al. (2018) added that chlorogenic acid, caffeic, ferulic, and quercetin affect the transport of carbohydrates and also influence as regulators in the release of satiety hormones. Furthermore, its effect was found to be even greater than that of conventional synthetic drugs and without the risk of causing any negative effect on the consumer. Based on in vivo animal studies, non-flavonoids help reduce the production of inflammatory agents such as monocyte chemoattractant protein-1 (MCP-1), cyclooxygenase-2 (COX-2), interleukin1 (IL-13), interleukin-8 (IL-8) or nitric oxide synthase (iNOS), important factors in the development of diabetes (Bhuyan \& Basu, 2017). According to the information collected by Ballard \& Junior (2019), flavonoids have action in increasing insulin secretion, metabolic regulation of glucose and flavanones especially, improve insulin resistance.

\subsubsection{Other health benefits}

In vitro studies report that flavonoids and anthocyanins reduce the viability of adipocytes, preventing the accumulation of triglycerides, improving the oxidation of fatty acids and reducing inflammation, demonstrating their effect against obesity (Ballard \& Junior, 2019).

Phenolic compounds also have an effect on the stimulation of the immune system. Research have determined that cinnamic and caffeic acid activate macrophages. Epicatechin gallate enhances the T cell; ferulic, chlorogenic and coumaric acids increase the secretion of cytokine interferon- $\gamma($ IFN- $\gamma$ ) (Bhuyan and Basu, 2017), both of which are important in the regulation of the immune system. Similarly, it was shown that phenols can act in the inhibition of endothelial dysfunction and mitochondrial dysfunction (Soto-Vaca et al., 2012).

Based on a study cited in Masibo \& He (2008), mangiferin reduces bad cholesterol and triglycerides in plasma and provides protection against radiation-induced disease. In another similar study, according to Zepeda-Ruiz et al. (2020), the consumption of the different parts of the Ataulfo mango for two months helped to improve the lipid profile and the antioxidant activity of plasma in people without any disease.

Also, El-Messery et al. (2021) demonstrated in vivo, using rats, that by giving them a milk drink with microcapsules of phenolic extract of mango peel, it was possible to increase the level of antioxidants and catalase, in addition to reducing the activity of lipid peroxidation, alalanine transaminase, aspartate transaminase and alkaline phosphatase decreased, thus preventing oxidative stress disorders.

\subsection{Use in the food industry}

3.2.1. Modification or enhancement of sensory qualities Bitterness and astringency in foods, an important characteristic in certain products, such as wine, beer (de Oliveira et al. 2014), nuts, chocolate, coffee, tea, which are conferred by anthocyanidins or condensed tannins (SotoVaca et al., 2012), or volatile polyphenols such as vanillin (El Gharras, 2009), could be enhanced and improved to positively influence consumer choice.

One of the factors influencing the taste of aged alcoholic beverages is the changes in phenolic compounds, for example, Soto-Vaca et al. (2012) mention that during the aging process of whiskey in barrels, ellagitannins are degraded and tannins are further oxidized, generating mixtures of castalagins, an ellagitannin that contribute to the flavor of the drink. With respect to tannins and their derivatives, Lebaka et al. (2021) indicate that $75 \%$ is in hydrolyzable form, so that prior to its use in food, it is necessary to process them, also reducing a possible risk of toxicity. Anthocyanins, flavanols and flavones are important pigments that also have an effect on food flavor. Proanthocyanidins can be used as copigments to produce red colors together with anthocyanins (de Oliveira et al., 2014). Anthocyanins are very reactive, as during the food processing process, they can affect the color, forming a wide variety of shades (El Gharras, 2009).

\subsubsection{Other applications as additives}

Phenolic compounds could be used as biopreservatives, enriching the antioxidant and antimicrobial capacity of fresh produce such as fruits and vegetables and of functional foods in general, free of synthetic additives which is currently of concern to the population because of their influence on health. For example, they have been effectively employed in the prevention of lipid oxidation of meat products such as hamburgers, sausages, nuggets and even margarine (Martillanes et al., 2017). Specifically, catechins are used as an additive to prevent oxidation of oils and fats, to reduce the microbial load and as a fortifier/enrichment of various food products (El Gharras, 2009). Concerning sunflower oil, in the research of Sánchez-Camargo et al. (2019), employing Sugar mango peel extract, at a ratio of 200 to 1000 ppm, which contained $64.8 \mathrm{mg} \mathrm{GAE} / \mathrm{g}$ and carotenoids (1.9 mg alltrans- $\beta$-carotene $/ g)$, it was possible to prevent its oxidation in an efficient and natural way.

Martillanes et al. (2017) mention that polyphenols could be incorporated in films and edible coatings, even in food packaging, obtaining an active packaging that prolongs its useful life and according to Arroyo et al. (2019), they could also enhance the physicochemical, nutritional and sensory 
characteristics with certain modifications or mixtures with other components that are considered.

Pacheco-Ordaz et al. (2017) concluded in their research that catechin, gallic, vanillic, ferulic and protocatechuic acid from mango by-products promoted the development of Lactobacillus rhamnosus and L. acidophilus, in addition to inhibiting the spread of E. coli and Salmonella typhimurium. Phenolic compounds demonstrated their use as a probiotic enhancer which can be applied in yogurt, cheese, olives, sauerkraut and other functional foods. According to the research of Mwaurah et al. (2020), they propose that the flour of the mango seed can partially substitute the wheat flour due to its antioxidant activity (73\% against $22.4 \%$ of the wheat flour), besides containing $44.21 \mathrm{UI} / 100 \mathrm{~g}$ of provitamin A, 1.03 and 0.45 $\mathrm{mg} / 100 \mathrm{~g}$ of tocopherol and ascorbic acid, respectively, and other components which would help to enhance the nutritional, physicochemical and sensory characteristics of the bread or other food products.

A particular case is that of Pérez-Chabela et al. (2021), who added mango peel flour in different proportions in a yogurt, managing to inhibit undesirable microorganisms and helping the proliferation of lactic acid bacteria, in addition to containing high levels of dietary fiber (35.41\%) and carbohydrates (40.08\%), providing a good prebiotic and fermentative effect in the preparation of this type of product. It should be noted that for the integration of mango byproducts in different formulations or food matrices, as specifically shown in Table 1, it is recommended that the extract be raw to ensure greater bioavailability of the compounds, considering that, due to its susceptibility, further processing would generate high levels of degradation.

\section{Methods of extraction and microencapsulation of phenolic compounds \\ 4.1. Extraction techniques}

There are many techniques for extracting phenolic compounds from mango peel and seed (Table 2). These must be easy to use, efficient, economical, and must extract the maximum number of compounds from the raw material, avoiding its degradation by the processing conditions (Mwaura et al., 2020).

Table 1

Application of phenolic compounds from mango by-products in food products

\begin{tabular}{|c|c|c|c|c|}
\hline $\begin{array}{c}\text { By-product/mango } \\
\text { variety }\end{array}$ & $\begin{array}{l}\text { Food } \\
\text { product }\end{array}$ & $\begin{array}{l}\text { Percentage of } \\
\text { application }\end{array}$ & Main findings & References \\
\hline Peel/Zebda & Cookies & $10 \%$ & $\begin{array}{l}\text { Increase in diameter by } 2.89 \mathrm{~mm} \text {, thickness by } 1.51 \mathrm{~mm} \text {, water } \\
\text { absorption by } 7.2 \% \text {, dough development time by } 8.5 \mathrm{~min} \text { and } \\
\text { stability by } 18 \mathrm{~min} \text {. Reduction in mixing tolerance by } 50 \mathrm{BU} \text { and } \\
\text { softening by } 10 \mathrm{BU} \text {. Increase of } 3.08 \mathrm{mg} \text { GAE/g and } 53.76 \% \mathrm{DPPH} \\
\text { activity. Overall acceptability improved, but not significantly. }\end{array}$ & $\begin{array}{l}\text { Ashoush \& } \\
\text { Gadallah } \\
\text { (2011) }\end{array}$ \\
\hline Peel/V.N.S. & Milk drink & $3 \% *$ & $\begin{array}{l}\text { Doubling and tripling of bioavailability during in vitro digestion with } \\
\text { values of } 2.42,6.36 \text { and } 8.25 \mathrm{mg} \text { catechin } / \mathrm{g} ; 6.62,46.53 \text { and } 64.61 \\
\text { mg rutin/g; DPPH activity of } 1.1,1.34 \text { and } 1.67 \mu \mathrm{mol} \text { TE/g; and FRAP } \\
\text { of } 0.85,3.52 \text { and } 3.87 \mu \mathrm{mol} \mathrm{TE} / \mathrm{g} \text {, in the oral, gastric and intestinal } \\
\text { stage, respectively, achieving a supplemented beverage. }\end{array}$ & $\begin{array}{l}\text { El-Messery } \\
\text { et al. (2021) }\end{array}$ \\
\hline Peel/Manila & Yogurt & $2 \%$ & $\begin{array}{l}\text { Syneresis reduction of } 0.7 \% \text {, viscosity increase of } 35.5 \% \text {, acidity of } \\
0.39 \text { grams lactic acid/L and } \mathrm{pH} \text { by } 0.3 \text {. Sensory characteristics were } \\
\text { affected, but not significantly, which did not influence the overall } \\
\text { high consumer acceptability. }\end{array}$ & $\begin{array}{l}\text { Pérez- } \\
\text { Chabela et } \\
\text { al. (2021) }\end{array}$ \\
\hline Seed/Nam-Dok-Mai & $\begin{array}{l}\text { White } \\
\text { shrimp }\end{array}$ & $0.5 \%$ & $\begin{array}{l}90 \% \text { decrease in polyphenol oxidase activity, total basic nitrogen } \\
\text { (from } 79.64 \text { to } 57.43 \mathrm{mg} \mathrm{N} / 100 \mathrm{~g} \text { ), thiobarbituric acid reactive } \\
\text { substances (from } 1.38 \text { to } 0.98 \mathrm{mg} \text { malanoaldehyde/kg), } \\
\text { psychrophilic bacteria index (from } 6.2 \text { to } 5.65 \mathrm{log} \text { CFU/g), inhibited } \\
\text { melanosis and prolonged shelf life during storage on ice for } 12 \text { days. }\end{array}$ & $\begin{array}{l}\text { Sai-Ut et al. } \\
(2020)\end{array}$ \\
\hline Peel/V.N.S. & $\begin{array}{l}25 \\
\text { desserts**}\end{array}$ & N.S. & $\begin{array}{l}\text { Optimum sensory performance in terms of appearance ( } 4.2 \text { to } 4.9) \text {, } \\
\text { color ( } 3.9 \text { to } 4.9 \text { ), texture ( } 3.8 \text { to } 4.9) \text {, odor ( } 4.2 \text { to } 4.8 \text { ) and flavor } \\
\text { ( } 3.7 \text { to } 4.9 \text { ), in addition to having an overall average acceptability of } \\
4 \text { to } 5 \text {, taking into account that the hedonic scale was from } 1 \text { to } 5 \text {, } \\
\text { from "poor" to "excellent". }\end{array}$ & $\begin{array}{l}\text { Thambi et } \\
\text { al. (2016) }\end{array}$ \\
\hline Peel/Tommy Atkins & $\begin{array}{l}\text { Kefir } \\
\text { during } \\
\text { fermentati } \\
\text { on }\end{array}$ & $5 \%$ & $\begin{array}{l}\text { Increased antioxidant activity DPPH (113\%) for } 10 \mathrm{~h} \text {, FRAP (153\%) for } \\
8 \mathrm{~h} \text {, ABTS ( } 21 \% \text { ) for } 6 \mathrm{~h} \text { and FRAP ( } 43 \%) \text { for } 8 \mathrm{~h} \text {, in addition to tripling } \\
\text { lactic acid bacteria (up to } 108 \mathrm{CFU} / \mathrm{mL} \text { ) during } 12 \mathrm{~h} \text {, helping to } \\
\text { obtain a better probiotic product. }\end{array}$ & $\begin{array}{l}\text { Vicenssuto } \\
\text { et al. (2020) }\end{array}$ \\
\hline Peel/Ataulfo & $\begin{array}{l}\text { Corn } \\
\text { chips }\end{array}$ & $15 \%$ & $\begin{array}{l}\text { Increase of } 8 \text { mg GAE/g and integration of 1950, } 63 \text { and } 49 \mu \mathrm{g} \\
\text { GAE/g of mangiferin, quercetin and rutin. Regarding digestive } \\
\text { bioavailability, phenolic content and DPPH activity had an increase } \\
\text { of } 378 \text { and } 401 \% \text { in the oral stage, } 239 \text { and } 194 \% \text { in the gastric stage, } \\
320 \text { and } 182 \% \text { in the intestinal stage. Likewise, there was no } \\
\text { difference with respect to overall acceptability }\end{array}$ & $\begin{array}{l}\text { Zepeda- } \\
\text { Ruiz et al. } \\
(2020)\end{array}$ \\
\hline \multicolumn{5}{|c|}{$\begin{array}{l}\text { V.N.S.: variety not specified; N.S.: not specified; FRAP: ferric reducing power; ABTS: (2'2-Azino-bis (3-ethylbenzthiazoline-6-sulfonic acid)); BU: Brabender unit, in } \\
\text { pharynography; CFU: Colony Forming Unit } \\
\text { *In the form of microcapsules; **Desserts: Alooparatha, dosai, idiyappam, kanchipuram idli, mango chutney, mini idli, ragi adai, vegetable pasta, bottle gourd } \\
\text { porial, cauliflower peas masala, channa masala, coconut rice, mango rice, paneer buter masala, sambar rice, tamarind rice, beet root halwa, custard, green gram } \\
\text { payasam, keasri, sprouts salad, sundal, sweet pongal, vegetable roll and yogurt. }\end{array}$} \\
\hline
\end{tabular}


The solvent is essential; the most suitable according to Ribeiro et al. (2020) are ethanol, methanol, acetone, diethyl ether, ethyl acetate, isopropanol and their mixtures with water, increase the efficiency of the process especially because they have a polarity close to that of phenolic compounds, which facilitates the diffusion stage. Likewise, it is essential to use green solvents that, in addition to helping to obtain quality products, avoid environmental impact. Based on Pal \& Jadeja (2020), there are deep eutectic solvents, which are based on natural products such as carbohydrates and organic acids, are low cost, non-toxic, non-flammable, recyclable and provide a significant quantity and quality of compounds during extraction. Some examples of mixtures used by the same authors in their study during the extraction of polyphenols from mango peel were choline chloride-sucrose, choline chloride-glycerol, choline chloride-lactic acid, choline chloride-malic acid and sodium acetate-lactic acid.

Briefly, the most commonly used extraction techniques are, in the first place, conventional extraction, also called solid-liquid or maceration extraction, where, quite simply, the solvent diffuses through the food using organic solvents. Despite being the most used due to its simplicity, it requires more time and quantity of solvent, which implies higher cost, in addition to the fact that this type of classical extractions, such as Soxhlet, by the use of high temperatures, thermolabile compounds are degraded (Meneses et al., 2015) and even more so polyphenols, which are very susceptible. To solve these drawbacks, other methods have emerged, such as ultrasoundassisted extraction, which uses frequencies (20 to $100 \mathrm{KHz}$ ) and vibrations that generate the degradation of the cell wall of the food, contributing to rapid extraction of phenols and avoiding their degradation by not requiring high temperatures, except for the conventional method (Tanase et al., 2019).

Another equally efficient technique is microwave-assisted, in which minimal amounts of solvent and time are used, focusing especially on the electromagnetic field ( 0.3 to $300 \mathrm{GHz}$ ), achieving that the kinetic energy produced by the waves, diffuses through the food matrix and achieving a high extraction rate (Pal \& Jadeja, 2020).

Table 2

Studies on the extraction of phenolic compounds from mango peel and seed

\begin{tabular}{|c|c|c|c|c|}
\hline $\begin{array}{l}\text { By-product/mango } \\
\text { variety }\end{array}$ & $\begin{array}{l}\text { Type of } \\
\text { extraction/solvent }\end{array}$ & Optimal process parameters & Main findings & References \\
\hline Seed/Manila & $\begin{array}{l}\text { Ultrasound/ } \\
\text { ethanol-water } \\
(80: 20)\end{array}$ & $\begin{array}{l}\text { t: } 30 \mathrm{~min} ; \mathrm{T}: 20^{\circ} \mathrm{C} ; \mathrm{f:} 20 \mathrm{KHz} \text {; } \\
\text { P: } 750 \mathrm{~W} \text {; A: } 50 \% \text {; } \\
\text { solvent/sample ratio: } 20 \mathrm{~mL} / \mathrm{g}\end{array}$ & $461.7 \mathrm{mg} \mathrm{GAE} / \mathrm{g}$ and $2919 \mu \mathrm{mol}$ TE/g & $\begin{array}{l}\text { Gómez- } \\
\text { Maldonado } \\
\text { et al. (2020) }\end{array}$ \\
\hline Peel/Keaw & $\begin{array}{l}\text { Subcritical } \\
\text { water/water }\end{array}$ & $\begin{array}{l}\text { t: } 40 \mathrm{~min} ; \mathrm{T}: 220^{\circ} \mathrm{C} ; \\
\text { solvent/sample ratio: } 80 \mathrm{~mL} / \mathrm{g}\end{array}$ & $99.69 \mathrm{mg} \mathrm{GAE} / \mathrm{g}$ & $\begin{array}{l}\text { Kantrong \& } \\
\text { Eshtiaghi } \\
(2018)\end{array}$ \\
\hline Peel/N.N.S. & $\begin{array}{l}\text { Maceration and } \\
\text { Ultrasonication/ } \\
\text { ethanol-acetone } \\
(60: 40)\end{array}$ & $\begin{array}{l}\mathrm{t}: 15 \mathrm{~min}, \mathrm{~T}: 20 \text { and } 25^{\circ} \mathrm{C} \text {; } \\
\text { solvent/sample ratio: } 20 \\
\mathrm{~mL} / \mathrm{g} ; \mathrm{f:} 24 \mathrm{KHz} \text { (for } \\
\text { ultrasound) }\end{array}$ & $\begin{array}{l}205.08 \text { and } 1493.01 \mathrm{mg} \mathrm{GAE} / 100 \mathrm{~g} \text {, } \\
\text { for both processes, respectively. } \\
\text { Antioxidant activity in ultrasound } \\
\text { alone was } 3.18 \text { and } 7.18 \mathrm{mg} \mathrm{TE} / 100 \mathrm{~g} \\
\text { for DPPH and ABTS. }\end{array}$ & $\begin{array}{l}\text { Martínez- } \\
\text { Ramos et al. } \\
(2020)\end{array}$ \\
\hline $\begin{array}{l}\text { Peel/Tommy Atkins } \\
\text { and Haden* }\end{array}$ & $\begin{array}{l}\text { Supercritical anti- } \\
\text { solvent/ } \mathrm{CO}_{2}\end{array}$ & $\mathrm{~T}: 40^{\circ} \mathrm{C} ; \Phi: 1 \mathrm{~mL} / \mathrm{min} \mathrm{p}: \mathrm{MPa}$ & $\begin{array}{l}\text { Recovery of } 90 \% \text {, obtaining } 16.83 \\
\text { mg/g, identifying mangiferin, iso } \\
\text { mangiferin, quercetin, kaempferol, } \\
\text { among others, in addition to a DPPH } \\
\text { test of } 851.9 \mu \mathrm{mol} \mathrm{TE} / \mathrm{g} \text {. }\end{array}$ & $\begin{array}{l}\text { Meneses et } \\
\text { al. (2015) }\end{array}$ \\
\hline Peel/Ataulfo & $\begin{array}{l}\text { Ultrasound- } \\
\text { microwave/ } \\
\text { methanol (50\%) }\end{array}$ & $\begin{array}{l}\text { t: } 10 \mathrm{~min} \text {; T: environmental; } \\
\text { solvent/sample ratio: } 5 \mathrm{~mL} / \mathrm{g} \text {; } \\
\text { f: } 2450 \mathrm{MHz} \text { for microwave } \\
\text { and } 25 \mathrm{KHz} \text { for ultrasound }\end{array}$ & $\begin{array}{l}54.15 \text { mg polyphenols/g and ABTS, } \\
\text { DPPH and lipid oxidation inhibition } \\
\text { activity of } 98.52,94 \text { and } 91.74 \% \text {, } \\
\text { respectively. }\end{array}$ & $\begin{array}{l}\text { Ordoñez- } \\
\text { Torres et al. } \\
(2020)\end{array}$ \\
\hline Peel/Kesar & $\begin{array}{l}\text { Microwave/sodium } \\
\text { acetate-lactic acid- } \\
\text { water }(1: 3: 4)\end{array}$ & $\begin{array}{l}\text { t: } 19.66 \text { min; T: environmental; } \\
\text { solvent/sample ratio: } 59.82 \\
\mathrm{~mL} / \mathrm{g} ; \mathrm{P}: 436.45 \mathrm{~W} \\
\end{array}$ & $\begin{array}{l}56.17 \mathrm{mg} \text { GAE/g, FRAP activity of } 683 \\
\mu \mathrm{mol} \text { ascorbic acid eq./g and } 82.64 \% \\
\text { DPPH inhibition. }\end{array}$ & $\begin{array}{l}\text { Pal \& Jadeja } \\
(2020)\end{array}$ \\
\hline $\begin{array}{l}\text { Mixture between } \\
\text { pulp, peel and } \\
\text { seed/Palmer }\end{array}$ & $\begin{array}{l}\text { Homogenizer } \\
\text { assisted/ethanol } \\
(70 \%)\end{array}$ & $\begin{array}{l}\text { t: } 5 \text { min; T: environmental; } \\
\text { solvent/sample ratio: } 29 \\
\text { mL/g; f: } 20500 \text { rpm }\end{array}$ & $\begin{array}{l}354.4 \text { and } 258.7 \text { mg mangiferin and } \\
\text { hyperoside/kg }\end{array}$ & $\begin{array}{l}\text { Zuin et al. } \\
(2020)\end{array}$ \\
\hline
\end{tabular}

V.N.S.: variety not specified; $t$ : time; T: temperature; f: frequency; p: pressure; $\Phi$ : fluid injection flow; P: power; A: amplitude; CE: catechin equivalent; IC50: concentration of the extract, required to eliminate half of the DPPH radicals. *Mixed peels of both mango varieties, with pulp residues. 
Emphasizing environmentally friendly techniques, extraction with supercritical fluids is the most appropriate, in addition to ensuring product quality. Mainly CO2 is used as it is safe, compatible with phenolic compounds and easy to eliminate afterwards (Sánchez-Camargo et al., 2019); additionally, achieving its supercritical phase is relatively simple as it requires low levels of temperature $\left(31^{\circ} \mathrm{C}\right)$ and pressure $(74$ bar). There is also a method employing subcritical water (100 to $320^{\circ} \mathrm{C}, 20$ to 150 bar), which is also sustainable, safe, efficient (Sánchez-Camargo et al., 2021) and especially, has a high penetration into the cell wall, considerably raising the recovery level of the compounds (Kantrong \& Eshtiaghi, 2018). The previously mentioned techniques are the most employed in the extraction polyphenols and, specifically, of mango peel and seed, as shown in Table 1, but there are also others that involve improvements or mixtures of the common ones such as accelerated solvent extraction (Tanase et al., 2019), conventional homogenizer-assisted (Zuin et al., 2020), ultrasound-microwave assisted (Ordoñez-Torres et al., 2020), supercritical antisolvent (Meneses et al., 2015) such as pulsed electric field extraction (Pattnaik et al., 2021), high hydrostatic pressure (Sánchez-Camargo et al., 2021), pressurized fluid (Martínez-Ramos et al., 2020) and enzymatic (Mwaurah et al., 2020).

It should be noted that, besides the type of extraction and solvent used (including its concentration), there are many more factors that influence the outcome of the process (Shirahigue \& Ceccato-Antonini, 2020), such as the nature of the feed, temperature, time, solvent/sample ratio, particle size, pH (Martínez-Ramos et al., 2020), agitation speed (Tanase et al., 2019) and specifically, depending on the process, other variables such as amplitude, power and frequency (Pattnaik et al., 2021).

What is remarkable in the extraction of polyphenols, besides their quality and quantity (56.23 and $28.33 \mathrm{~g}$ total phenols/100g of dry matter in the peel and seed of mango var. Keitt, respectively, according to the results of Dorta et al., 2014), is their subsequent use as an additive, taking advantage of their properties without affecting the quality of the food. For example, Mercado (2014) extracted the phenolic compounds from the Haden mango seed which showed a DPPH and ABTS antioxidant capacity of 2034.1 and 4205.7 $\mu \mathrm{mol} \mathrm{TE} / \mathrm{g}$. The extracts were applied to fresh cut mangoes previously inoculated with E. coli, Salmonella typhimurium, Staphylococcus aureus and L. monocytogenes, inhibiting them, without affecting the characteristics of the fruit, according to the sensory evaluations.

\subsection{Microencapsulation techniques}

To ensure that phenolic compounds remain stable without altering their composition and beneficial properties, from extraction to consumption, it is necessary to prevent their deterioration by applying technologies or techniques such as microencapsulation, which has recently been used for the protection of phenolic extract of mango peel and seed (Table 3). Ribeiro et al. (2020) mention that this technique protects the compounds by incorporating them into an ideal matrix, preserving qualities, functionalities and with the opportunity to improve them.

In addition, Pattnaik et al. (2021) mention that it the advantage of controlling its release in the gastrointestinal tract so that the consumer can take full advantage of its properties, which is indispensable today.

The most commonly employed process is spray drying for its simplicity. According to Ozkan et al. (2019), this continuous physical-mechanical process is based on feeding the compound with the coating polymer in the dryer, they are mixed and then, inside a chamber provided with hot air, upon contact, the particles evaporate, dry, are separated by a cyclone and are collected as powder, which is affected by parameters such as feed flow, type and percentage of the coating material, temperature and flow of the drying air, among others. Another microencapsulation method widely used due to the use of low temperatures is freeze-drying, which consists of freezing $\left(<0{ }^{\circ} \mathrm{C}\right)$ of the emulsion, subsequent sublimation, by means of vacuum pressure to finally obtain powder microcapsules, with low moisture level and high porosity due to the slow freezing process (Pattnaik et al., 2021). Another physical method is extrusion, which consists of passing the liquid solution formed between the compound and the encapsulating material through an orifice, and as a result of gravity, surface tension, momentum and friction, droplets are formed and then dried. The size of the powder is mainly affected by the diameter of the orifice (Ribeiro et al., 2020).

Regarding the physicochemical processes of microencapsulation of polyphenols from mango peel and seed, according to the literature, methods such as microencapsulation with ultrasound have also been employed. Pattnaik et al. (2021) mention that, due to the sound waves, bubbles are generated and grow at the food/polymer emulsion interface. Subsequently, the lowfrequency acoustic intensity causes shearing, which results in the breaking of the emulsion, forming smaller particles.

There are other techniques that have also been widely used for the microencapsulation of phenols from various raw materials and also other bioactive compounds. Some, based on Ozkan et al. (2019); Ribeiro et al. (2020) are physical processes such as fluidized bed, interfacial polymerization and coacervation (simple or complex), chemical processes such as co-crystallization, ionic gelation, double emulsion and supercritical fluids, in addition to physicochemical ones such as liposome formation and molecular inclusion.

Regardless of the process, an important factor is the selection of the coating material, which has a direct influence on the performance of the microcapsules, their characteristics and subsequent release (Lim et al., 2019). It is essential that the encapsulant must provide emulsifying properties, be biodegradable, resistant to the intestinal tract, have low viscosity and hygroscopicity, provide maximum protection to the nucleus against adverse conditions, without being reactive with it, lack flavor and have economic viability, in order to be suitable in the food field. There are many coating agents, Ozkan et al. (2019) emphasize polysaccharides such as starches, maltodextrins, chitosan, gums, agar, cellulose and alginate, proteins such as gelatin and albumin, but lipids such as wax, paraffins, lecithin and glycerides are also used. When choosing the ideal microencapsulation technique, factors such as the complexity of the method, the cost and whether it can be done continuously or discontinuously according to our requirements should also be considered. 
Table 3

Recent research on the microencapsulation of phenolic extract from mango peel and seed

\begin{tabular}{|c|c|c|c|c|}
\hline $\begin{array}{l}\text { By-product/mango } \\
\text { variety }\end{array}$ & $\begin{array}{l}\text { Type of process/coating } \\
\text { material }\end{array}$ & $\begin{array}{l}\text { Optimal process } \\
\text { parameters }\end{array}$ & Main findings & References \\
\hline Peel/V.N.S. & $\begin{array}{l}\text { Ultrasound/maltodextrin } \\
\text { and whey protein } \\
\text { concentrate }(20: 80)\end{array}$ & $\begin{array}{l}\mathrm{t:} 1 \mathrm{~h}, \mathrm{~T}: 50-60^{\circ} \mathrm{C} ; \\
\mathrm{CM}: 10 \%, \mathrm{P}: 160 \mathrm{~W} ; \mathrm{f} \\
20 \mathrm{kHz}\end{array}$ & $\begin{array}{l}303.4 \mathrm{~nm} \text { particle size, with a Zeta } \\
\text { potential* of }-24.76 \mathrm{~V} \text { and } 80.99 \% \\
\text { encapsulation efficiency }\end{array}$ & $\begin{array}{l}\text { El-Messery et } \\
\text { al. (2021) }\end{array}$ \\
\hline Seed/V.N.S. & $\begin{array}{l}\text { Spray- } \\
\text { drying/maltodextrin }\end{array}$ & $\begin{array}{l}\mathrm{T}_{\mathrm{ai}}: 150{ }^{\circ} \mathrm{C} ; \mathrm{CM}: 10 \% \\
\text { Ф: } 25 \mathrm{~g} / \mathrm{min} ; \mathrm{p}: 0.1 \\
\mathrm{MN} / \mathrm{m}^{2}\end{array}$ & $\begin{array}{l}127 \mathrm{mg} \text { GAE} / \mathrm{g} \text { and } 217,700 \mathrm{mmol} \\
\text { TE/100 g DPPH, } 0.32 \mathrm{~g} / \mathrm{cm} 3 \text { bulk } \\
\text { density, 3.17\% moisture and } 88.75 \% \\
\text { water solubility index and a yield } \\
>60 \% \text {. }\end{array}$ & Lim et al. (2019) \\
\hline Seed/V.N.S. & $\begin{array}{l}\text { Spray- } \\
\text { drying/maltodextrin }\end{array}$ & $\begin{array}{l}\mathrm{T}_{\mathrm{ai}}: 150^{\circ} \mathrm{C} ; \mathrm{CM}: 8 \% ; \\
\mathrm{p}: 0.1 \mathrm{MPa}\end{array}$ & $\begin{array}{l}\text { 3.56\% moisture, } 2.58 \% \text { water } \\
\text { absorption rate, } 96.14 \mathrm{mg} \text { GAE/g, } \\
129.46 \mathrm{mmoL} \text { ET/g DPPH, } 24.28 \% \\
\text { maximum water solubility index plus } \\
\text { acceptable color }\end{array}$ & $\begin{array}{l}\text { Siacor et al. } \\
(2020)\end{array}$ \\
\hline
\end{tabular}

V.N.S.: variety not specified; t: time; Tai: air inlet temperature; T: temperature; CM: concentration of the coating material; f: frequency; p: pressure; $\Phi$ : feed flow rate; p: pressure; A: amplitude

*A measure of attraction or repulsion between microparticles, which directly determines their stability.

Based on information from Ozkan et al. (2019); Ribeiro et al. (2020), Figure 5 shows that the level of complexity is proportionally direct to the cost of processing, but in addition, the same relationship can be considered with respect to the type of production which can be discontinuous ( $\mathrm{g} / \mathrm{h})$, semi-continuous $(\mathrm{kg} / \mathrm{h})$ or continuous (ton/h). For example, spray drying can be used or adapted without much difficult to a continuous scale, fluidized bed to a semi-continuous scale and ionic gelation to a discontinuous scale.

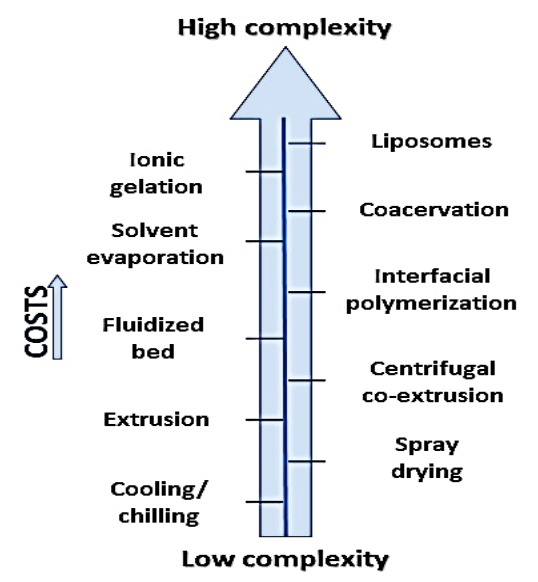

Figure 5. Relationship complexity - type of process and its influence on the cost of microencapsulation techniques.

\section{Current and future challenges}

According to the various studies conducted on the phenolic potential of mango peel and seed and the properties it confers on them, they are a promising ingredient that could be used for pharmacological and food purposes (Ashoush \& Gadallah, 2021). Their use would also allow a circular economy (Alañón et al., 2021) that, in addition to replacing the use of synthetic additives, which often have negative impacts on health (Pal \& Jadeja, 2020), would reduce chemical and microbiological contamination, resulting from the decomposition of byproducts. However, it is necessary to deepen in their properties to know the different effects they can cause when interacting with the food matrix, in contact with other compounds, in different doses and the type of benefit to be obtained; for example, considering the antimicrobial effect, in the elaboration of yogurt in the study of Pérez-Chabela et al. (2021), only pathogenic bacteria and other fungi and yeasts were inhibited, allowing the growth of lactic acid bacteria, which was ideal for fermentation, positively influencing the final quality of the product.

Regarding the extraction and microencapsulation methods, the different variables involved in the process should be thoroughly investigated in order to improve them, achieving optimal levels of polyphenols and antioxidant activity, as well as increasing bioavailability in the gastrointestinal digestion stage. In the research of Pattnaik et al. (2021), a precise analysis of these processes was carried out. They especially emphasized the use of emerging non-thermal technologies to avoid degradation of the compounds and, the use of safe solvents during extraction, such as $\mathrm{CO}_{2}$, water or deep eutectics. It is also advisable to analyze the use of combined techniques to optimize the process and try to apply it on a large scale, a promising challenge for the food field.

\section{Conclusions}

Mango peel and seed contain a large amount and variety of phenolic compounds with a high antioxidant and antimicrobial activity. These qualities can be exploited especially for their potential health benefit, in addition to contributing to a circular economy and to the reduction of environmental pollution generated by the decomposition of the aforementioned by-products. 
It was evidenced by research their mechanism of action antimicrobial by the chemical interaction that causes various effects on the structure of the bacterial and fungal cell membrane, up to causing death, and antioxidant by stabilizing free radicals, chelation of metals and inactivation of enzymes, important factors in food preservation and also in the prevention of several diseases, especially chronic. Moreover, the various applications of phenolic compounds in the food industry were determined, standing out as a functional ingredient due to their capacity to influence the sensory and physicochemical characteristics of the foods, without affecting their quality.

Finally, as processing technologies, concerning extraction and microencapsulation, there are a wide variety of methods; therefore, in order to obtain better results, it is necessary to improve them and experiment with the use of combined techniques, taking into account that they are environmentally friendly.

\section{ORCID}

V. Tirado-Kulieva (D) https://orcid.org/0000-0001-8534-9153

S. Atoche-Dioses (D) https://orcid.org/0000-0001-8393-6784

E. Hernández-Martínez (D) https://orcid.org/0000-0003-3839-3244

\section{References}

Alañon, E., Taamalli, A., Zarrouk, M., Carretero, A. S., \& Román, D. A. (2017). Natural phenolic compounds and parkinson's disease. In: GardeCerdán, T.; Gonzalo-Diago, A.; Pérez-Álvarez, E.P. (Ed.). Phenolic compounds: types, effects and research. Nova Science Publishers. New York. Pp. 1-28.

Alañon, M. E., Pimentel-Moral, S., Arráez-Román, D., \& Segura-Carretero, A. 2021. HPLC-DAD-Q-ToF-MS profiling of phenolic compounds from mango (Mangifera indica L.) seed kernel of different cultivars and maturation stages as a preliminary approach to determine functional and nutraceutical value. Food Chemistry, 337, 127764.

Arroyo, B. J., Santos, A. P., de Melo, E. A., Campos, A., Lins, L., \& BoyanoOrozco, L.C. (2019). Bioactive compounds and their potential use as ingredients for food and its application in food packaging. In: Segura M. (Ed.). Bioactive Compounds: Health Benefits and Potential Applications. Woodhead Publishing. Duxford. Pp. 143-156.

Ashoush, I. S., \& Gadallah, M. G. E. (2011). Utilization of Mango Peels and Seed Kernels Powders as Sources of Phytochemicals in Biscuit. World Journal of Dairy \& Food Sciences, 6(1), 35-42.

Bai, X., Lai, T., Zhou, T., Li, Y., Li, X., \& Zhang, H. (2018). In vitro antioxidant activities of phenols and oleanolic acid from mango peel and their cytotoxic effect on a549 cell line. Molecules, 23(6), 1395

Ballard, C. R., \& Junior, M. R. M. (2019). Health benefits of flavonoids. In Campos, M.R.S. (Ed.). Bioactive Compounds: Health Benefits and Potential Applications. Woodhead Publishing. Duxford. Pp. 185-201.

Ben-Othman, S., Jõudu, I., \& Bhat, R. (2020). Bioactives from agri-food wastes: present insights and future challenges. Molecules, 25(3), 510

Bhuyan, D. J., \& Basu, A. (2017). Phenolic compounds: potential health benefits and toxicity. In: Young, Q.V. (Ed.). Utilisation of Bioactive Compounds from Agricultural and Food Waste. CRC Press. Florida. Pp. 27-59.

Bouarab-Chibane, L., Forquet, V., Lánteri, P., Clément, Y., Léonard-Akkari, L., et al. (2019). Antibacterial properties of polyphenols: characterization and QSAR (quantitative structure-activity relationship) models. Frontiers in Microbiology, 10, 829.

Castro-Vargas, H. I., Vivas, D. B., Barbosa, J. O., Medina, S. J. M., Gutiérrez, F. A., \& Parada-Alfonso, F. (2019). Bioactive phenolic compounds from the agroindustrial waste of colombian mango cultivars 'Sugar Mango' and 'Tommy Atkins' - an alternative for their use and valorization. Antioxidants, 8(2), 41-59

de Oliveira, L. L., de Carvalho, M. V., \& Melo, L. (2014). Health promoting and sensory properties of phenolic compounds in food. Revista Ceres, 67 764-779.

Dorta, E., González, M., Lobo, M. G., \& Laich, F. (2016). Antifungal activity of mango peel and seed extracts against clinically pathogenic and food spoilage yeasts. Natural Product Research, 30(22), 2598-2604.

Dorta, E., González, M. Lobo, M.G. Sánchez-Moreno, C. \& de Ancos, B. (2014). Screening of phenolic compounds in by-product extracts from mangoes (Mangifera indica L.) by HPLC-ESI-QTOF-MS and multivariate analysis for use as a food ingredient. Food Research International, 57 51-60.

El Gharras, H. (2009). Polyphenols: food sources, properties and applications - a review. International Journal of Food Science \& Technology, 44(12), 2512-2518.

El-Desoukey, R. M. A., Aljor, N. M., \& Alaotibi, A. D. (2020). The phytochemical and antimicrobial effect of mango (Mangifera indica $L$.) peel extracts on some animal pathogens as eco-friendly. Acta Scientific Microbiology, 3(4), 34-39.

El-Messery, T. M., El-Said, M. M., Salama, H. H., Mohammed, D. M., \& Ros, G. (2021). Bioaccessibility of Encapsulated Mango Peel Phenolic Extract and its Application in Milk Beverage. International Journal of Dairy Science, 16(1), 29-40.

Gómez-Maldonado, D., Lobato-Calleros, C., Aguirre-Mandujano, E., LeyvaMir, S. G., Robles-Yerena, L., \& Vernon-Carter, E. J. (2020). Antifungal activity of mango kernel polyphenols on mango fruit infected by anthracnose. LWT - Food Science and Technology, 126, 109337.

Gordo, D. A. M. (2017). Los compuestos fenólicos, un acercamiento a su biosíntesis, síntesis y actividad biológica. Revista de Investigación Agraria y Ambiental, 9(1), 81-104.

Hole, A. S., Grimmer, S., Jensen, M. R., \& Sahlstrøm, S. (2012). Synergistic and suppressive effects of dietary phenolic acids and other phytochemicals from cereal extracts on nuclear factor kappa b activity. Food Chemistry, 133(3), 969-977.

Huang, C. Y., Kuo, C. H., Wu, C. H., Kuan, A. W., Guo, H. R., et al. (2018). Free radical-scavenging, anti-inflammatory, and antibacterial activities of water and ethanol extracts prepared from compressional-puffing pretreated mango (Mangifera indica L.) peels. Journal of Food Quality, 2018(1), 1-13.

Kantrong, A., \& Eshtiaghi, M. N. (2018). Extraction of Phenolic Compounds from Mango Peel using Subcritical Water Technique. Kasem Bundit Engineering Journal, 8, 75-86

Lebaka, V.R., Wee, Y.J., Ye, W., \& Korivi, M. (2021). Nutritional Composition and Bioactive Compounds in Three Different Parts of Mango Fruit. International Journal of Environmental Research and Public Health, 18, 741.

Lemus-Molina, Y., Sánchez-Gómez, M. V., Delgado-Hernández, R., \& Matute, C. (2009). Mangifera indica $L$. extract attenuates glutamate-induced neurotoxicity on rat cortical neurons. Neurotoxicology, 30(6), 1053-1058

Lim, K. J. A.; Cabajar, A. A.; Migallos, M. K. V.; Lobarbio, C. F. Y., \& Taboada, E. B. (2019). Microencapsulation of phenolic compounds from waste mango seed kernel extract by spray drying technology. Nature Environment and Pollution Technology, 18(3), 765-775.

Maqsood, S., Benjakul, S., Abushelaibi, A., \& Alam, A. (2014). Phenolic compounds and plant phenolic extracts as natural antioxidants in prevention of lipid oxidation in seafood: a detailed review. Comprehensive Reviews in Food Science and Food Safety, 13(6), 11251140.

Marcillo-Parra, V., Anaguano, M., Molina, M., Tupuna-Yerovi, D. S., \& Ruales, J. (2021). Characterization and quantification of bioactive compounds and antioxidant activity in three different varieties of mango (Mangifere indica L.) peel from the Ecuadorian region using HPLC-UVNIS and UPLC-PDA. NFS Journal, 23, 1-7.

Martillanes, S., Rocha-Pimienta, J., Cabrera-Bañegil, M., Martín-Vertedor, D., \& Delgado-Adámez, J. (2017). Application of phenolic compounds for food preservation: food additive and active packaging. In: SotoHernández, M.; Palma-Tenango, M. \& García-Mateos, R. (Ed.). Phenolic Compounds: Biological Activity. IntechOpen. Londres. Pp. 39-58.

Martín, M. D., Iriondo-DeHong, A., \& Bilbao, M. D. C. (2018). Efecto de los compuestos fenólicos en el metabolismo de los carbohidratos. Revista Española de Nutrición Comunitaria, 24(1), 1-12

Martínez-Flórez, S., González-Gallejo, J., Culebras, J. M., \& Tuñón, J. (2002). Los flavonoides: propiedades y acciones antioxidantes. Nutrición Hospitalaria, 17(6), 271-278.

Martínez-Ramos, T., Benedito-Fort, J., Watson, N. J., Ruiz-Lopez, I. I., CheGalicia, G., \& Corona-Jiménez, E. (2020). Effect of solvent composition and its interaction with ultrasonic energy on the ultrasound-assisted extraction of phenolic compounds from Mango peels (Mangifera indica L.). Food and Bioproducts Processing, 122, 41-54.

Masibo, M., \& He, Q. (2008). Major Mango Polyphenols and their potential significance to human health. Comprehensive Reviews in Food Science and Food Safety, 7(4), 309-319.

Meneses, M. A.; Caputo, G.; Scognamiglio, M., Reverchon, E., \& Adami, R. (2015). Antioxidant phenolic compounds recovery from Mangifera indica L. by-products by supercritical antisolvent extraction. Journal of Food Engineering, 163, 45-53.

Mercado, A. T. B. (2014). Impacto sensorial de un extracto antioxidante y antibacteriano de semilla de mango aplicado en mango fresco cortado var. Haden. Tesis de maestría, Centro de Investigación en Alimentación y Desarrollo, Sonora. México. 92 pp.

Minatel, I. O, Borges, C. V., Gomez, H. A. G., Chen, C. Y. O., \& Lima, G. P. P. (2017). Phenolic compounds: functional properties, impact of processing 
and bioavailability. In: Soto-Hernández, M.; Palma-Tenango, M. \& García-Mateos, R (Ed.). Phenolic Compounds: Biological Activity. IntechOpen. Londres. Pp. 1-24.

Mwaurah, P. W., Kumar, S., Kumar, N., Panghal, A., Attkan, A. K., et al. (2020) Physicochemical characteristics, bioactive compounds and industrial applications of mango kernel and its products: A review. Comprehensive Reviews in Food Science and Food Safety, 19, 2421-2446

Ochoa, M. C. I., \& Ayala, A. A. A. (2004). Los flavonoides: apuntes generales y su aplicación en la industria de alimentos. Ingeniería y competitividad, 6(2), 64-74

Ordoñez-Torres, A., Torres-Leon, C., Hernández-Almanza, A., Flores-Guía, T., Luque-Contreras, D., et al. (2020). Ultrasound-microwave-assisted extraction of polyphenolic compounds from Mexican "Ataulfo" mango peels: Antioxidant potential and identification by HPLC/ESI/MS. Phytochemical Analysis, 37, 1-8.

Ozkan, G., Franco, P., De Marco, Y., Xiao, J., \& Caponoglu, E. (2019). A review of microencapsulation methods for food antioxidants: Principles, advantages, drawbacks and applications. Food Chemistry, 272, 494-506

Pacheco-Ordaz, R., Wall-Medrano, A., Goñi, M. G., Ramos-ClamontMontfort, G., Ayala-Zavala, J. F., \& González-Aguilar, G. A. (2017). Effect of phenolic compounds on the growth of selected probiotic and pathogenic bacteria. Letters in Applied Microbiology, 66(1), 25-31.

Pal, C. B. T., \& Jadeja, G. C. (2020). Microwave-assisted extraction for recovery of polyphenolic antioxidants from ripe mango (Mangifera indica L.) peel using lactic acid/sodium acetate deep eutectic mixtures. Food Science and Technology International, 26(1), 78-92.

Pattnaik, M., Pandey, P., Martin, G. J. O., Mishra, H. N., \& Ashokkumar, M. (2021). Innovative Technologies for Extraction and Microencapsulation of Bioactives from Plant-Based Food Waste and Their Applications in Functional Food Development. Foods, 10, 279

Pérez-Chabela, M. L., Cebollón-Juárez, A., Bosquez-Molina, E., \& Totosaus, A. (2021). Mango peel flour and potato peel flour as bioactive ingredients in the formulation of functional yogurt. Food Science and Technology, Epub March 08, 2021.

Quiñones, M., Miguel, M., \& Aleixandre, A. (2012). Los polifenoles, compuestos de origen natural con efectos saludables sobre el sistema cardiovascular. Nutrición Hospitalaria, 27(1), 76-89.

Raybaudi-Massilia, R. M., Mosqueda-Melgar, J., Soliva-Fortuny, R., \& MartínBelloso, O. (2009). Control of pathogenic and spoilage microorganisms in fresh-cut fruits and fruit juices by traditional and alternative natural antimicrobials. Comprehensive Reviews in Food Science and Food Safety, 8(3), 157-180.

Ribeiro, A. M., Estevinho, B. N., \& Rocha, F. (2020). Microencapsulation of polyphenols - The specific case of the microencapsulation of Sambucus Nigra L. extracts - A review. Trends in Food Science \& Technology, 105, 454-467.

Ribeiro, S. M. R., Barbosa L. C. A., Queiroz J. H., Knodler, M., \& Schieber, A. (2008). Phenolic compounds and antioxidant capacity of Brazilian mango (Mangifera indica L.) varieties. Food Chemistry, 110(3), 620-626.

Rojas, R., Alvarez-Pérez, O. B., Contreras-Esquivel, J. C., Vicente, A., Flores, A., Sandoval, J., \& Aguilar, C.N. (2018). Valorisation of Mango Peels: Extraction of Pectin and Antioxidant and Antifungal Polyphenols. Waste and Biomass Valorization, 11, 89-98.

Sai-Ut, S., Noknoi, N., \& Nakjai, N. (2020). Effect of mango seed kernel extract on polyphenol oxidase inhibition and shelf life of shrimp during iced storage. Agricultural and Natural Sciences, 54, 641-648.

Sánchez-Camargo, A. P., Ballesteros-Vivas, D., Buelvas-Puello, L. M. Martinez-Correa, H. A., Parada-Alfonso, F., et al. (2021). Microwaveassisted extraction of phenolic compounds with antioxidant and anti- proliferative activities from supercritical $\mathrm{CO} 2$ pre-extracted mango peel as valorization strategy. LWT - Food Science and Technology, 137, 110414

Sánchez-Camargo, A. P. Gutiérrez, L. F., Vargas, S. M., Martinez-Correa, H. A., Parada-Alfonso, F., \& Narváez-Cuenca, C. E. (2019). Valorisation of mango peel: Proximate composition, supercritical fluid extraction of carotenoids, and application as an antioxidant additive for an edible oil. The Journal of Supercritical Fluids, 152, 104574

Shirahigue, L. D., \& Ceccato-Antonini, S. R. (2020). Agro-industrial wastes as sources of bioactive compounds for food and fermentation industries. Ciencia Rural, 50(4), e20190857

Siacor, F. D. C., Lim, K. J. A., Cabajar, A. A., Lobarbio, C. F. Y., Lacks, D. J., \& Taboada, E.B. (2020). Physicochemical properties of spray-dried mango phenolic compounds extracts. Journal of Agriculture and Food Research, 2, 100048.

Soong, Y. Y., \& Barlow, P. J. (2004). Antioxidant activity and phenolic content of selected fruit seeds. Food Chemistry, 88(3), 411-417.

Soto-Vaca, A., Gutierrez, A., Losso, J. N., Xu, Z., \& Finley, J. W. (2012). Evolution of phenolic compounds from color and flavor problems to health benefits. Journal of Agricultural and Food Chemistry, 60(27), 6658-5577.

Struck, S. \& Rohm, H. (2020). Fruit Processing by-products as food ingredients. In: Galanakis, C.M. (Ed.). Valorization of Fruit Processing Byproducts. Academic Press. Massachusetts. Pp. 1-16.

Sumaya-Martínez, M. T., Medina-Carrillo, R. E., González-Ocegueda, E. Jiménez-Ruíz, E. I., Balois-Morales, R., et al. (2019). Mango (Mangifera indica L.) pulping byproducts: antioxidant activity and bioactive compounds of three mango cultivars. Revista Bio Ciencias, 6, e560.

Tanase, C., Cosarca, S., \& Muntean, D. L. (2019). A critical review of phenolic compounds extracted from the bark of woody vascular plants and their potential biological activity. Molecules, 24(6), 1182.

Thambi, P. A., John, S., Lydia, E., lyer, P., \& Monica, S. J. (2016). Antimicrobial efficacy of mango peel powder and formulation of recipes using mango peel powder (Mangifera indica L.). International Journal of Home Science, 2(2), 155-161

Vega-Vega, V., Silva-Espinoza, B. A., Cruz-Valenzuela, M. R., Bernal-Mercado, A.T., González-Aquilar, G.A., et al. (2013). Antimicrobial and antioxidant properties of byproduct extracts of mango fruit. Journal of Applied Botany and Food Quality, 86(1), 205-211.

Velderrain-Rodríguez, G. R., Acevedo-Fani, A., González-Aguilar, G. A. \& Martín-Belloso, O. (2019). Encapsulation and stability of a phenolic-rich extract from mango peel within water-in-oil-in-water emulsions. Journal of Functional Foods, 56, 65-73.

Vermerris, W., \& Nicholson, R. (2006). Phenolic Compounds and their Effects on Human Health. In: Vermerris, W. \& Nicholson, R. (Ed.). Phenolic Compound Biochemistry. Springer. New York. Pp. 235-253.

Vicenssuto, G. M., \& de Castro, R. J. S. (2020). Development of a novel probiotic milk product with enhanced antioxidant properties using mango peel as a fermentation substrate. Biocatalysis and Agricultural Biotechnology, 24, 101564

Zepeda-Ruiz, G. C., Domínguez-Avila, J. A., Ayala-Zavala, J. F., RoblesSánchez, M., Salazar-López, N. J, et al. (2020). Supplementing corn chips with mango cv. 'Ataulfo' peel improves their sensory acceptability and phenolic profile, and decreases in vitro dialysed glucosa. Journal of Food Processing and Preservation, 44, e14954.

Zuin, V. G., Segatto, M. L., \& Zanotti, K. (2020). Towards a green and sustainable fruit waste valorisation model in Brazil: optimisation of homogenizer-assisted extraction of bioactive compounds from mango waste using a response surface methodology. Pure and Applied Chemistry, 92(4), 617-629 